\title{
SPECIFICATIONS OF PARTICIPATORY BUDGETING IN VISEGRAD GROUP STATES AND POSSIBLE IMPLEMENTATIONS FOR SLOVAKIA
}

\author{
Dalibor Mikušr ${ }^{1}$ Richard Brix ${ }^{2}$, Daniel Šmatlánek ${ }^{3}$
}

\begin{abstract}
Participatory budget is an innovative tool for public policymaking, which is characterized by the particpation of residents of territorial administrative units. In the paper, authors focus on the evaluation of the participatory budget within the Visegrad Group, which is linked by specific ties due to the special development of this geopolitical area after the political and social changes in the late 1980s. Identifying the specifics of participatory budgeting in Poland, the Czech Republic, Hungary, and Slovakia is set as the main goal of the article, specifically evaluating the pilot project model, analysing the legislative framework, which regulates participatory budgeting, and extending this tool at the local level in terms of current statistics. As for the pilot projects, the authors identified differences in the following indicators: initiator of its implementation; participation of citizens and their position and powers in project design; participation in the decision-making on projects in terms of voting; whether a direct physical vote or online form was used. In addition, the authors evaluate the legal framework of the selected states in terms of presence of the primary or secondary regulation. Finally, the quantitative development of participatory budgets is monitored, while the potential impact of the COVID-19 pandemic is also reflected in the paper. Based on the data from other states of the Visegrad Group, in the final chapter the authors present optimization proposals, which they consider applicable in Slovakia. The authors identified at least three possible ways of amending the current Slovak legislation in order to improve the implementation of the participatory budget. The paper specifies the shortcomings in the form of low citizen participation in the drafting phase and in the voting process. The paper also identifies the same bottom-up implementation process in all V4 member countries. Poland is the only V4 country that has enshrined primary legislation on participatory budgets in its legal system.
\end{abstract}

KEY WORDS: Participatory budgeting, Civil engagement, Visegrad Group, Participation, Tools.

\footnotetext{
${ }^{1}$ Faculty of Social Sciences, University of Ss.Cyril and Methodius in Trnava, Bučianska 4/a 91701 Trnava, Slovakia. E-mal: dalibor.mikus@ucm.sk.

${ }^{2}$ Faculty of Social Sciences, University of Ss.Cyril and Methodius in Trnava, Bučianska 4/a 91701 Trnava, Slovakia. E-mal: richard.brix@ucm.sk.

${ }^{3}$ Faculty of Social Sciences, University of Ss.Cyril and Methodius in Trnava, Bučianska 4/a 91701 Trnava, Slovakia. E-mal: daniel.smatlanek@gmail.com.
} 


\section{INTRODUCTION}

Civic participation is undoubtedly one of the main pillars of democratic political systems. Norris (2002) claims that mass participation is a lifeblood of representative democracy. A relatively innovative tool classifiable under the content of this term - participatory budgeting - leads to empowering and stabilizing those political systems, which are perceived as democratic ones (Buele et al., 2020).Thanks to the tool, citizens gain power to take decisions on financial sources of their administrative unit. There is a presumption that the tool also playes role in the countries with their undemocratic past. The Visegrad countries are included in this group and they are the focus countries of this paper. The research is aimed at the countries that are mutually connected with a common heritage of socialist regimes led by communist parties. Political and society changes emerging at the turn of the 80s and 90s opened them a path to democracy. Their transformations into democracies were made for the purpose of implication of democratic tools. Based on these facts, the authors here identify various forms of application of civic participation and empowering the civil society. Enlargement of participatory budgeting within the Visegrad countries in the recent decade may be understood as a tool for deepening their democracy. However, the setting of participatory budgets in Slovakia, the Czech Republic, Poland, and Hungary is not uniform, as they are influenced by a specific range of factors. The primary goal of the paper is to identify differences in the area associated with participatory budgeting in the Visegrad Group countries based on the comparing the criteria below. The object of comparison are the participatory budgets of local governments in the four designated countries. The selection is influenced, on the one hand, to the already mentioned common history that had an important influence on their political and social environment. At the same time, it is worth to mention that several international comparative studies involving these countries are published currently by authors such as Marczewska-Rytko eds. (2018) or Vráblíková (2009), however on more general topic, such as political participation. Although some publications that follow participatory budgeting in the V4 countries could be found, such as Civic/Participatory Budget in the Visegrad Group Countries in the Context of Good Practices (Marczewska-Rytko, Maj, 2021), however, not completely comparative in their nature, as this paper is based on. In the process of addressing this matter, the research also relied on the authors of the Visegrad Group, who deal with the models of participatory budgets in the individual countries. 
Under this research, these participatory budgets were monitored in those countries from the initial implementation of the pilot project to the present. In order to identify differences in participation in the V4 countries' budget, these areas were monitored, namely the pilot projects and their settings, legislative frameworks at the national levels, and the number of participatory budgets used as it has developed there. As for the pilot projects, the research monitored differences in the following indicators: initiator of its implementation; involvement of citizens and their position and powers in project design; involvement in the decision-making on projects in terms of voting; whether it was a direct physical vote or on-line form was used. The legislative framework was monitored through identifying the primary or secondary regulation in the legal frameworks. Finally, the quantitative development of participatory budgets in the individual countries was monitored, with a reflection put on the potential impact of the COVID-19 pandemic here. Therefore, the authors distinguish between the intention to implement the projects by local governments and their real application in practice, which was perceived as the only objective criterion.

In terms of the set goal of the article and the identified research areas, the following research questions are defined: How the V4 countries differ in the case of pilot years? What differences in the legislative framework of the V4 countries are identified? What are the differences within the V4 countries in the development of participatory budgets since the pilot years were introduced?

Data from civic associations, non-profit organizations, or databases of state administration bodies of the individual countries comprise as the source data in this study. Comparative conclusions are introduced based on the observation of methodological procedures.

The paper is structured into 4 main parts. First, the current knowledge of the topic is provided by a review of literature as this issue has already been a matter of research; therefore, several significant papers are mentioned, which provided significant information for this research and contributed on extending the scope of the research herein. Second, there is part of the work where basic terms associated with participatory budgeting are presented. The theory is followed by a practical and comparative implementation of participatory budgeting in each of the Visegrad Group countries. In each of the selected countries, pilot projects and initial development of participatory budgeting are described. Moreover, there are legal conditions analysed. Finally, the findings are discussed with the answers the research questions provided before the final part is concluded. 


\section{LITERATURE REVIEW}

Globally, participatory budgeting is a relatively well-researched issue, although it considered an innovative tool for civic participation. Since the introduction of this instrument in Porto Allegre in 1989, several models have been developed based on the political, economic and social specificities of each country. Thus, the authors deal predominantly with specific applied models of participatory budgeting, emphasizing special system elements. In general, this paper considers Cabannes (2015), Wampler (2012), Goldfrank (2006), Sintomer, Röcke and Herzberg (2016), Krenjova and Raudla (2013), Baiocchi and Ganuza (2015), Dias ed. (2018) as the most influential authors. The latter is an editor of the extensive work Hope for Democracy: 30 Years of Participatory Budgeting Worldwide (Dias ed., 2018), which is a collection of a wide range of articles covering the experiences with implementing participatory budgets in different parts of the world.

When focusing on specific areas of the issue, several approaches need to be identified. Sintomer, Herzberg and Röcke (2008) generated common characteristics of participatory budgets based on the analysis of different models. They try to set out the theoretical basis of the issue applicable in general. The same intention could be observed in Wampler (2012), who defined the necessary criteria for participatory budgets. In this context, he clearly specifies the criteria as some of the actions are carried out within a participatory mechanism without direct use of this tool. Krenjova and Raudla (2013) deal with the specifics of participatory budgets in the European area, defining the common features within the setting. They declare a very different concept of the instrument compared to the practice of the states of South America, where the participatory budget was primarily an element of social policy and solidarity in society.

The issue of participatory budgeting is also the subject of research in Slovakia, although its application in real practice is linked only to the recent decade. The legislative framework and classification of models are identified in the works of authors such as Székely (2020), Čunderlík (2015), Murray Svidroňová and Gondášová (2016), Brutovská and Marošiová (2019) or Garaj and Bardovič (2020). If the focus is on solving specific cases of practice of applied participatory budgets in local governments, then there are several papers dealing with the issue papers by as Brutovská, Hrehová (2019), Hrabinová et al. (2020), Brix (2020), Mikuš and Novák (2020). In the case of authors Hrabinová et al. (2020), Klimovský and Gašparík (2020), an effort to prepare a guidance for participatory budgets based on examples 
of good practice is apparent. Cevárová (2020) complements these studies by evaluating strengths and weaknesses through SWOT analysis. Bardovič and Gašparík (2021) deal with current impact of the Covid-19 crisis on the implementation of participatory budgets in Slovakia. They point to the objective fact of stopping individual processes at the local and regional level. In Poland, the most significant authors in the issue are Markowski (2019), Džinić, Murray Svidroňová and Markowska-Bzducha (2016), Keblowski and Van Criekingenb (2014), and Gerwin and Grabkowska (2012). Their studies evaluate the positive examples of local governments, while emphasizing the benefits of applying this instrument in terms of deepening participation. In the case of the Czech Republic, significance of the publication by Brabec (2019) needs to be emphasized as it evaluated the development of participatory budgets in the period 2014-2018. Although the participatory budgeting model is the least developed in Hungary, authors such as Sipos, Reszkető (2019) or de Vries, Nemec, Špaček eds. (2021) deepen their interest in the issue in terms of the possibilities of applying the tool in practice.

\section{THEORETICAL INTERPRETATION OF PARTICIPATORY BUDGETING}

In the theoretical definition, the participatory budget is recognised as an element of modernization of public administration and applied mechanisms. It is based on the need to deepen civil society by transferring decision-making directly to the hands of citizens. According to Allegreti and Copello (2018) the participatory budgeting has been one of the most important tools of civic engagement, especially over the last two decades. In the primary setting, the needs of the community are met, based on which the convergence of local politics with the will of the citizens is identified. Ganuza and Baiocchi (2012) emphasize that space is being created for the integration of diverse activities into the public sphere. The application of this mechanism partially transfers elements of the private sector to the public sphere. However, despite these general characteristics, there is no uniform definition of participatory budgeting, which is based on the specific development of this instrument in different parts of the world.

However, the authors of this papers consider the real practice from the city of Porto Alegre in 1989 to be a basic milestone, where a pilot project had all it started. The introduction of a participatory budget was based on the specifics and peculiarities of developments throughout Brazil, which was in the process of slow democratization after the elimination of the military dictatorship. According to Friant (2017), in public space the 
country suffered from corruption and clientelism, which was reflected in deepening disparities among the population. This phenomenon could be also demonstrated by the situation in the city of Porto Alegre with poor development of the peripheral parts. According to Fedozzi (2007), financial resources went primarily to richer middle- and upper-class areas, as they had great impact on political power. The lower class living on the outskirts of the city did not have the functional tools to participate in decision-making processes. The change came with the victory of the left-wing Workers' Party, which advocated for active participation mechanisms by allocating part of the funds from the public budget. According to Sintomer, Röcke and Herzberg (2016), the model proved to be an optimal tool for solving economic disparities in a specific case, as several positive elements were identified.

Based on that, the World Bank took the initiative and became an important organization in expanding the participatory budget in the world. However, the political, economic, and cultural specifics of individual countries were reflected in the creation of differentiated models. Cabannes (2015) emphasizes that, especially within the Western democracies, the transformation of participatory budget from a mere tool for balancing disparities to a tool of deepening civic participation and democracy as such could be observed. Therefore, authors such as Buele et al. (2020) or Marczewska-Rytko eds. (2018) understand participatory budgeting as a set of specific cases created under the influence of specific factors.

At the theoretical level, however, there is an academic discussion held on what a participatory budget represents today. As there is no uniform definition, this part of the paper summarizes the key criteria of some authors dealing with the issue by setting the criteria for participatory budgeting.

According to Peixot, each participatory budget should meet the following seven characteristics (Dias ed., 2018):

- The subject of participatory budgeting is a defined part of the public budget;

- Civic participation has a direct impact on budget creation;

- Protecting the interests of the community by applying a deliberative element;

- Long-term repetition of the process;

- An institutional framework is established to ensure the control function of the management of public finances;

- Process settings with redistribution elements are present;

- Citizens do co-decide on the rules of the process. 
However, several authors define a lower number of mandatory characters. According to Dias ed. (2018), a participatory budget should ensure the participation of all citizens without any privileges for organizations. The setting of the rules is based on the will of individual members. The authority of power oversees the allocation of investments considering the technical criteria of the given self-governing unit. Sintomer, Röcke, and Herzberg (2016) present five principles where the element of shared responsibility dominates. The percentage share of the participatory budget, which is assigned, should be based on agreements between citizens and representative bodies. Wampler (2012), on the other hand, set three basic objectives for a participatory budget, as they follow:

- Active citizenship associated with public education;

- Achieving of social justice;

- Administrative apparatus is reformed.

It thus focuses on another aspect of the process in the form of educating its participants. Citizens join municipal policy through a participatory budget, as they have a direct opportunity to influence the decisions. They acquire important information in terms of tools applied in public policy making. When they are active in submitting the projects, they become a part of individual procedures, which also require certain professional qualities. Repeating the whole mechanism in a time horizon longer than a year gives the opportunity to rise the knowledge of the stakeholders willing to achieve the implementation of projects. Citizens participating in the vote are equally drawn into the municipal sphere as they become directly acquainted with the needs of the territorial unit and the possibilities of solutions. Ultimately, this strengthens civic democracy in terms of active citizenship. Neubauerová and Zubal'ová (2012) also emphasize the element of empowering mutual trust between citizens and self-government - identified here as benefits in both directions. On the one hand, the legitimacy of decisions taken by local government representatives is growing significantly, on the contrary, the local level is becoming a stabilizing element of the entire democratic establishment. Citizens gain trust in the administration, and therefore optimize the performance of the administration.

Beside positive impact of participatory budgeting, there is also a eventual reverse side. According to Keblowski and Van Criekingenb (2014) there are some features of the process that could be seen a potential negative aspect of the tool: 
- Debates are obviously taken rarely;

- The criteria for verification of the projects are imprecise;

- The projects scope proves just small diversity;

- Participatory budgeting could serve as a tool for improving the image of local stakeholders.

Based on theoretical reflection, it could be argued that the process of participatory budgeting is a set of unique cases created under the influence of specific political, economic, and social factors. There is no universal model. Authors, who deal with the matter, only summarize the experience from different cases and identify the common features of the basic characteristics. The application of this instrument could probably improve the progress of civil society and democratic principles. At the same time, a new kind of political culture emerges with the direct involvement of the citizen. Ultimately, there is an increase of need for principles such as transparency, education, and solidarity. The importance of the benefits of the participatory budget is thus growing significantly in the geopolitical space of the Visegrad Group, within which they are linked by the legacy of communist regimes and the ongoing democratization process.

\section{APLICATION OF THE PARTICIPATORY BUDGET IN THE V4 COUNTRIES}

Based on the research questions and criteria established in the first part of the paper, differences in the case of pilot years of participatory budgets are identified within the countries of the Visegrad Group countries. Specifically, the research required to evaluate the criteria of the initiators of the introduction of participatory budgets, the participation of the population in terms of competence in project design, and the form of voting in the decision-making process.

Sintomer, Röcke, and Herzberg (2016) consider Poland as a key player in expanding the participatory budget in the geopolitical area of the Visegrad Group not only because the participatory budgeting is considered as public consultation (Pomaranski, 2016). Based on criteria, the authors classify the project of the city of Sopot in 2011 as the first participatory budget case. In this context, however, it should be emphasized that the first attempt at public-private participation was already associated with the city of Plock in 2003-2005. Due to the cooperation of the local government, intergovernmental organizations, and the private oil company Orlen, a 
grant fund was established for providing the opportunity for projects to be submitted by citizens. Virtually, the oil company provided funds for the development of the city, while a mechanism of civic participation was created in cooperation with the local government. The individual proposals were subsequently evaluated by an expert commission that assessed the technical requirements and feasibility of the projects. In this case, however, Keblowski and Van Criekingenb (2014) point out the lack of decisionmaking and the absence of citizens in the voting itself.

In terms of theoretical background, the Sopot model met the set criteria, as citizens were incorporated into individual phases and directly decided on the use of local budget. The initiator of the whole project was the non-profit organization Sopot Development Initiative (Sopocka Inicjatywa Rozvojova). The city with 38,000 inhabitants is one of the most developed in terms of socio-economic indicators. One of the crucial indicators, for instance, the unemployment rate, which in 2011 reached only 3.6\% compared to the national average exceeding 13\% (Bezrobocie rejestrowane, 2011). The initiative from the non-profit sector received the support of members of the political party Law and Justice (PiS), which meant the enforcement of the proposal in the municipal council. Therefore, application of the bottomup initiator principle may be declared here. The model itself was not based on a specific allocation of funds within the budget - this occurred only in the final phase. At first, a participatory budget commission was created by the self-governing bodies in order to cover the whole process and ensure a comprehensive agenda. The staff consisted of the city hall members and members of the city council. One of the primary tasks was to launch an information campaign by addressing each household. Residents received a brochure containing the individual points of the participatory budget together with a form for submitting projects. Then, rallies were organized within the districts that represented the city districts.

Discussions led to the identification of problems and the submission of projects. As no financial framework was set at first, their financial scope and thematic framework were not limited. The task of the commission was to assess compliance with applicable laws and regulations, the city's zoning plan, and the adequacy of financial costs. The voting was of a combined nature and took place at the level of city districts and the city. The time frame was set at 6 days, with residents given option to vote either directly in the polling stations or by electronic means. The age limit was set at 18 years, and since 2013 it has been reduced to 15 years. After the results were published and the winning projects were announced, the self-government undertook 
to incorporate them into the budget, under the responsibility of the mayor. The whole process was completed by City Council's vote on the final form of the budget. In practice, however, it was only a formal step in terms of project implementation. In summarizing the whole process, shortcomings could be identified in the form of an insufficient level of citizen participation of $1.4 \%$, which could be considered as low (Gerwin, Grabkowska, 2012). On the other hand, the importance of the pilot project is indispensable in terms of the expansion of the tool in Poland, which is also confirmed by some other authors such as Markowski (2019), Džinić, Murray Svidroňová and Markowska-Bzducha (2016), Keblowski and Van Criekingenb (2014), or Madej (2019).

Compared to Poland, the application of the pilot project in the Czech Republic emerged in late 2014. It was the non-governmental organizations Agora Central Europe and Alternativa zdola who initiated the process. The first project initiative was established in 1998, advocating the strengthening of democratic mechanisms with an emphasis on improving cooperation between the state administration and citizens (Mimovládní organizace Agora CE, 2021). The latter emphasized the presentation of foreign models and the offer of alternatives to governance. Modernization of public administration and civic participation were key elements of action. In cooperation with some of the city councils they published initial documents such as "Methodology for the creation of participatory budgets in the Czech Republic"(Mimovládní organizace Agora CE, 2021) or "Handbook of participatory budgeting"(Černý, 2016). At the same time, they organized seminars aimed at local government representatives to support this concept. An important milestone was the conference held in 2012 in Most entitled "Participation - a greater chance for the citizen", which was attended by more than 100 representatives of local governments. The extension of the idea of a participatory budget was reflected in the application of the pilot model within the Prague 7 district. At the same time, the city council set aside a resolution of $1,000,000$ Czech crowns. Through organized public debates, citizens submitted 20 projects, of which only one of which was to win. The vote consisted of a special procedure in several rounds. In the first, the participatory budget committee examined the technical requirements of the projects. After the first phase, the 7 projects proceed to the voting process by citizens. This took place exclusively directly, within 4 voting rooms over a period of two weeks (Brabec, 2019). Lack of information during campaign, criticised by the NGOs during the campaigning, subsequently reflected in low rate of participation. At the same time, the NGOs' criticism pointed to the low financial resources 
allocated by the local government. Despite several shortcomings, the model of the Prague 7 district represents an important milestone in applying the instrument of the participatory budget. However, it should be emphasized that the first project was discontinued a few years later because the new city administration did not consider the tool to be a priority after the 2014 municipal elections (Černý, 2016).

A pilot project was conducted in Slovakia in 2011 in Bratislava with the non-profit organization Utopia playing a key role. They considered the participatory budget to be an innovative tool for involving citizens in decision-making, based on good practicies countries such as Spain and Italy. After a series of seminars focused on local governments, in 2011, the City of Bratislava was acquired for this idea. It is worth mentioning that this made Bratislava the second European capital applying this instrument. The pilot project was carried out under specific conditions, with a fund of $15000 €$ allocated exclusively from sponsors. The city council therefore did not spend any part of public funds in this process. Thus, the entire organizational structure was a bottom up- structure. However, the role of the municipality was to determine the thematic areas that focused on youth, seniors, culture, environmentalism and the development of bicycle transport. Citizens could choose a maximum of 3 projects from each area based on deliberation (Džinić, Murray Svidroňová and Markowska-Bzducha, 2016). However, the method of voting, which preferred the online form, could be seen critically. The intergovernmental organization also drew attention to other facts concerning the allocated funds or the information campaign. In the first case, although the municipality increased funding to $29,975 €$ in 2012 and in 2014 to $46,000 €$, it was still very far from the original promise of the capital's administration to allocate $1 \%$ of the public budget. In the second case, the information campaign was carried out almost exclusively by the Utopia volunteers, i.e. from the intergovernmental organization without any significant involvement of the municipality. Disagreements were eventually reflected in the transfer of participatory budgeting to urban areas.

Although Hungarian pilot project was applied in 2016, this is the the least developed tool in V4 countries. According to Sipos and Reszketo (2019), centralization of power and lack of political will are the main reasons beyond this fact. Representatives of the ruling Fidesz party were not interested in deepening civil society by developing forms of civic participation. The pilot project was implemented within the district of Budapest, where the opposition enjoyed a majority. Specifically, it was Kispest designated as District XIX with the dominance of the socialist parties. The Green Party, 
as a smaller coalition partner in cooperation with non-profit organizations, initiated the introduction of this mechanism. Here, the citizens could directly decide on 16 projects. However, in this case, they did not have the power to make proposals, as they voted on projects submitted by local authorities. The voting itself took place as a direct vote without online form available (Oross, Kiss, 2021). The pilot project became the initial impetus for the development of this tool, while another local part of Budapest District XXII applied a participatory budget in 2019. In Hungary, the 2019 municipal elections were the impetus for the development of the participatory budget. Hungary is therefore an exception within the Visegrad Group. However, 2019 municipal elections brought the change with an opposition candidate Gergely Karácsony winning in the capital city. He considered PB an important tool of direct democracy in terms of involving the city's inhabitants in decision-making. The pilot project was officially launched on 1 October 2020, with the city council allocating approximately 2.9 million euros from the budget ( 1 trillion forints). Due to the pandemic crisis, citizens only could to present their suggestions exclusively online. At the end of the year, more than 700 proposals were collected (DemNet, 2021). In the first step of the evaluation process, the city council assessed the technical requirements and duplication of the projects, based on which 142 projects were generated. Subsequently, they were evaluated by a commission composed of representatives of local government and citizens. Finally, 53 projects were introduced to the inhabitants of the city to decide in their final vote, online again. Either these were projects of a city-wide nature or related only to a specific district. Based on 13,344 votes, there were 15 winning projects (Budapest's participatory budget greenlights 15 projects worth HUF 1 billion, 2021). In this context, it should be emphasized that the actual realization of the projects has not been implemented yet. The successful completion of the participatory budget process in Budapest represents an important milestone for the application of this instrument in Hungary and can be a significant impetus for its extension to other municipalities.

Taking regard to the set criteria and the second research question, this section deals with the identification of differences in the case of the legislative setting within the Visegrad Group. Based on the evaluation of the models of individual states, this is to claim that Poland is the only with the primary regulation of participatory budgets adopted at the national level. In Poland, the whole process began in 2009, when the law on participatory budgeting in Poland was adopted as a result of discussions between the government and intergovernmental organizations. The law 
defined financial transactions for local governments to deepen citizens' participation in decision-making processes. Local assemblies have acquired the power to consult with residents on the main problems and challenges of the municipality (Markowski, 2019). However, unclear legal regulation led to an arbitrary interpretation of local governments. In practice, the standardization of elements of the participatory budget in legislation was absent. This did not happen until the adoption of the Act of 31 January 2018, based on which the participatory budget was recognized as a "special form of social consultation". The legal norm stipulates the power of the inhabitants to decide directly once a year on part of the expenditures from the municipal budget based on a resolution of the municipal authorities. However, the obligation to apply a participatory budget is only limited to larger cities with the character of a polish district (powiat). At the same time, the amount of funds was set at the amount of at least $0.5 \%$ of expenditures. On the contrary, self-governing bodies have the competence to define by resolution the formal requirements that a given project should meet. On this basis, the rules of participatory budgeting are adjusted annually based on the evaluation of the previous years. When it comes to the right to participate at the local level in Poland, most Polish cities accept voting regardless of age, and some of the cities ask voting under a supervision only.

Related to the outbreak of the Covid-19 crisis, some criticism from local governments couldbeobservedas theyareobliged toimplementparticipatory budgets. Specifically, there are 66 places with a powiat status, where the main officials demanded to amend the law. Their arguments concerned the negative effects of the Covid-19 crisis, reflected in reduced local government tax revenues. In the crisis-time, they considered the implementation of participatory budgets an economic burden. However, the amendment to the law regarding the abolition of the obligation of participatory budgets for a given category of cities did not find support of the MPs of the Sejm in April 2020 (Baranowski, 2020). It can be thus observed that primary regulation, on a practical level, largely negates flexibility in terms of adapting to new conditions. Concerning other states of the Visegrad Group, only secondary regulation at the level of individual local governments is identified. At the same time, however, guidance on participatory budgets was created by nonprofit organizations. In the Czech Republic, this paper already emphasized the importance of Agora Central Europe and "Alternatíva zdola", in the case of Slovakia, the intergovernmental organization Utópia.

Regarding the third research question, the development of participatory budgets was quantitatively evaluated from their introduction to the present. 
In this context, however, it should be emphasized that the continuous growth of participatory budgets within the local governments of Poland, the Czech Republic and Slovakia was significantly disrupted by the outbreak of the Covid-19 crisis in 2020. As a result, several municipalities suspended the participatory budget process, or this process even did not start at all. In terms of objective indicators, this research presents an evaluation of the years from the implementation of pilot projects to 2019 with the effects of the Covid-19 crisis included in the present evaluations.

After the pilot project was introduced in Sopot in 2011, authors such as Džinić, Murray Svidroňová and Markowska-Bzducha (2016) consider the model in Dabrowa Gornicza from 2013 to be a milestone in shaping the tradition of participatory budgeting. It has largely optimized the original setting with some innovations introduced. The financial framework in the expenditure part of the budget was set aside at an early stage. Greater emphasis was placed on the information campaign, while the voting itself was held in 3 forms - direct voting, electronic and postal voting. These facts were reflected in a relatively high participation rate of $22.3 \%$. Following the successful introduction of a participatory budget within individual local governments, this tool has been rapidly expanded in Poland. Although accurate statistics are not centrally recorded, according to a study by the University of Economics in Wrocław, the participatory budget was applied in 50 municipalities in 2013, in 2014 in more than 150, with the figure ranging from 220 to 250 municipalities in 2019 (Bednarska-Olejniczak, Olejniczak, 2021). As we mentioned above, the problematic point was the obligation of participatory budgets in the cities with powiat status even after the outbreak of the Covid-19 crisis. Based on information available from individual municipalities, the number of implemented participatory budgets in 2020 increased within almost 90 local governments. In the case of 66 municipalities with an obligatory setting, practical performance was carried out in accordance with minimum criteria based on the law.

Similarly, to the case of the Czech Republic, following the above-mentioned pilot project in Prague 7, the development of this tool is extending to several local authorities. In 2015 new attempts of the participatory budget appeared in Prague district 10, Prague - Zbraslav and in the city of Semily located in the Liberec region. Among the larger cities, Brno was the first to apply the participatory budget in the Czech Republic (Participativní rozpočet, 2020). 
Graph 1: Number of Czech Municipalities that Apply Participatory Budgeting (2014-2019)

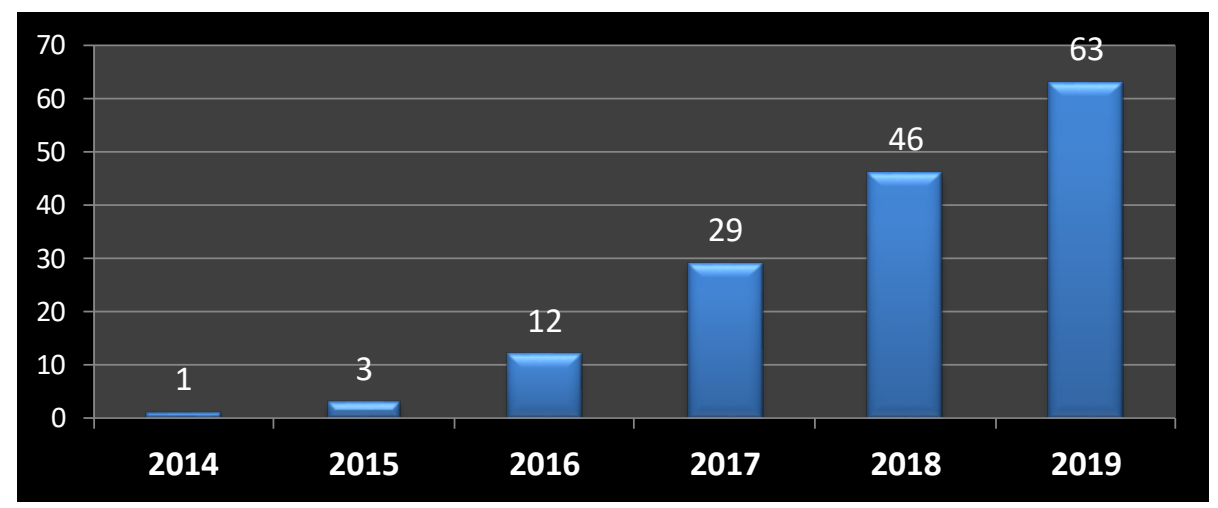

Source: the authors, based on Agora CE data from the intergovernmental organisation

However, the problem is that the proportion of public funds remains relatively low and the level of citizen participation remains low. Considering the benchmarks for 2019, the highest share of the public budget of $2.38 \%$ was allocated in the small town of Golčùv Jeníkov in the Vysočina region with less than 2,700 inhabitants. On the contrary, in the case of larger cities like Brno or Pilsen, this share reached $0.22 \%$, and/or $0.03 \%$. The indicator of the financial share of the budget allocated to the participatory budget is reflected in the scope of citizen participation. Golčův Jeníkov reached $24 \%$ in the voting and $6.36 \%$ of citizens involved in project proposals. In contrast, Brno achieved results of $5.45 \%$ and $0.35 \%$ in these indicators; equally low percentages is also identified in the case of Pilsen, $6.19 \%$, and $1.99 \%$ (Participatívní rozpočty v České republice, 2019). Brno has a population of 380,000 and therefore slightly more than 20,000 people were involved, in case of Plzen this number counts around 10,000. If it comes to participatory budgeting in the Czech Republic, the self-government units basically offer both ballot voting and electronic voting (Minárik, 2020). Most of the projects relate to environment, sport, civic amenities. The low number of participation rates could also partly attribute to poor marketing activities. However, the effects of the Covid-19 crisis were also reflected in the case of the Czech Republic by disrupting individual processes. However, according to data released by the non-profit organization Agora CE, almost two thirds of the participatory budgets were implemented, while the vote was modified to an online form. (Participatívni rozpočet, 2020). 
Evaluating the Slovak case, the same trend could be observed as in the case of Poland and the Czech Republic. After the pilot project in Bratislava, a modified model was launched within a district of Bratislava - Petržalka, in 2013. Overall contribution of civic citizens was strengthened by option to choose one project in the categories of new greenery, public spaces, and sports. The Bratislava - Nové Mesto district applied the "Porto Alegre for Europe" model with the support of public voting in the form of deliberation with a fixed share of $50 \%$. In addition, direct votes contributed to $30 \%$ weight within 11 polling stations and online voting represented $20 \%$ of the votes cast (Výsledky participatívneho rozpočtu, 2014). At the same time, it could be argued that the thematic areas were also selected by the citizens directly at the first session of the commission. The importance of these projects in the initial phase was reflected in the relatively rapid spread of this tool among local governments in Slovakia.

Graph 2: Number of Slovak Municipalities that Apply Participatory Budgeting (2014-2019)

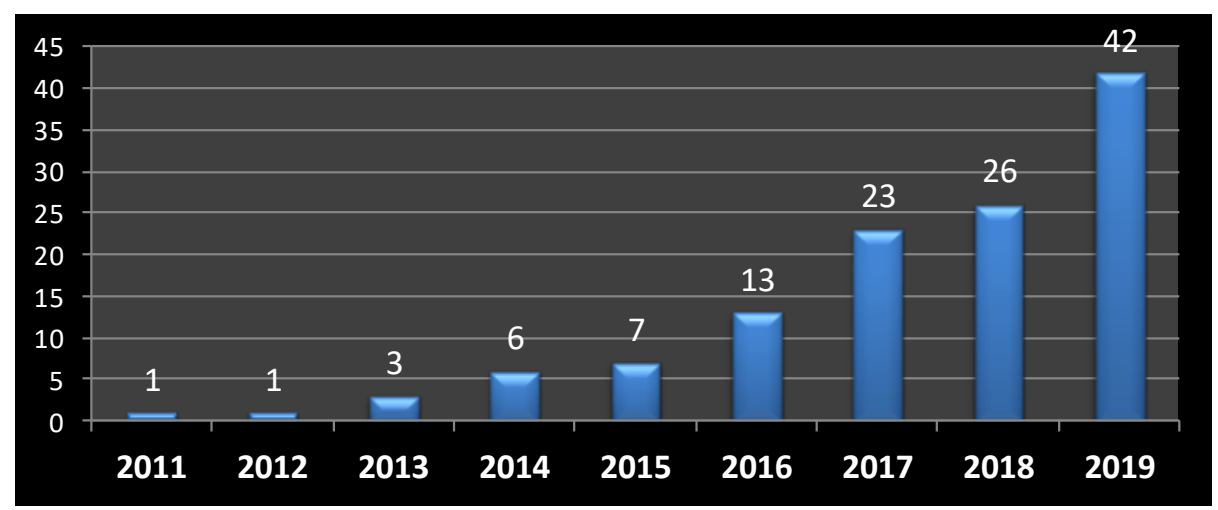

Source: the authors, based on the data of Utópia NGO

The graph clearly illustrates the development of the participatory budget in Slovak municipalities. After the initial success of participatory budgeting in Bratislava, it was applied in Ružomberok in 2013 and in Banská Bystrica in 2014. Among regional cities, it is necessary to emphasize its introduction in 2016 in Trnava and two years later in Nitra. The most significant expansion took place in 2019, when, after positive experiences and the presentation of good practice, participatory budgeting was adopted in 17 local governments, including the High Tatras, Považská Bystrica, and Pezinok. 
However, the outbreak of the Covid-19 crisis was marked by the abolition of some participatory budgets, resp. extension of the set period to 2 years. According to the data collected from individual local governments, in 2020 the regular year was closed only in the case of 17 local governments (Bardovič, Gašparík, 2020).

\section{DISCUSSION AND PROPOSALS}

The participatory budget is a relatively widespread tool of civic participation within the Visegrad Group as identified here via evaluation of the individual states. Over the last decade, it has become an important element of municipal policy, especially in Poland, the Czech Republic, and Slovakia, and is based on long-term cooperation between local governments and non-governmental organizations. These are the countries - initiators, which launched the whole process inspired by the foreign models. Therefore, pilot projects were introduced in 2011 in Poland and Slovakia, in 2014 in the Czech Republic, and in 2016 in Hungary. In the case of Poland, it should be emphasized that the first attempt at public-private participation in the town of Plock was identified even in 2003-2005, however, this did not meet the criteria of a participatory budget. The research presented above highlighted the shortcomings in involving the citizens in the design phase and in the voting process. In all 4 countries of the Visegrad Group, a bottom-up implementation process was identified. As far as voting itself is concerned, only in the case of Sopot in Poland a combined voting was applied in terms of direct voting in polling stations with online form. Subsequently, however, when expanding participatory budgets, models were developed considering combined voting as an optimal way of involving as many people as possible in the process.

Regarding the second research question, the research findings identified the primary legislative anchoring at the national level in Poland only. It is practically the only country with standardized criteria besides Portugal, Italy, and Spain. At the same time, in Poland since 2018, the legislation imposes an obligation to implement participatory budgets in cities with district status, which is assessed here as problematic, especially during the Covid-19 crisis. Thus, the local governments required some change in this setting arguing a decline in tax revenues. In the case of the Czech Republic, Slovakia, and Hungary, PB is based on secondary legislation adopted at the level of local governments. Considering the third research question, this research has identified a continuous increase in participatory budgets since 
the introducing the pilot projects in the individual states of the Visegrad Group. However, the marked milestone is associated with the outbreak of the Covid-19 crisis in 2020, when some participatory budgets were cancelled, or postponed to a two-year cycle.

Table 1: Summary of the Specifics of Participatory Budgets in the Visegrad Group Countries

\begin{tabular}{|c|c|c|c|c|c|c|}
\hline 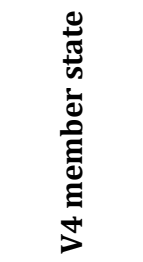 & 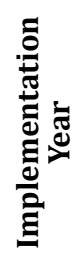 & $\begin{array}{l}\frac{\tilde{U}}{0} \\
\frac{d}{0} \\
\frac{0}{0} \\
\frac{0}{2}\end{array}$ & $\begin{array}{l}\stackrel{\Xi}{0} \\
:\end{array}$ & 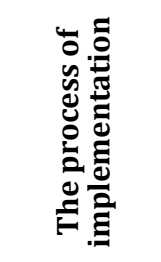 & 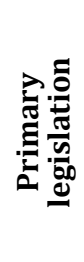 & 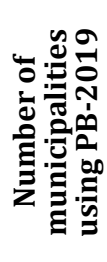 \\
\hline Poland & 2011 & Sopot & $\begin{array}{c}\text { NGOs/ } \\
\text { municipality }\end{array}$ & Bottom-Up & Yes & 250 \\
\hline $\begin{array}{c}\text { Czech } \\
\text { Republic }\end{array}$ & 2014 & $\begin{array}{l}\text { Praha } 7 \\
\text { (District) }\end{array}$ & $\begin{array}{c}\text { NGOs/ } \\
\text { municipality }\end{array}$ & Bottom-Up & No & 63 \\
\hline Slovakia & 2011 & Bratislava & $\begin{array}{c}\text { NGOs/ } \\
\text { municipality }\end{array}$ & Bottom-Up & No & 42 \\
\hline Hungary & 2016 & $\begin{array}{l}\text { Budapest- } \\
\text { Kispest } \\
\text { District XIX }\end{array}$ & $\begin{array}{c}\text { NGOs/ } \\
\text { municipality }\end{array}$ & Bottom-Up & No & 2 \\
\hline
\end{tabular}

Source: the authors

Considering the case of Slovakia since 2011, the participatory budget has undergone a special development in the environment of local governments. The quantitative indicator clearly shows the success of this instrument, while the qualitative element is difficult to evaluate. Each self-governing unit has the power to create own specific model, as no standardized form is regulated by legislation. The free will of self-governing bodies of municipalities and cities has been reflected in differentiated models, which in some cases are between the participatory budget and the subsidy scheme. Thus, the citizens are not delivered enough space in deciding on allocation of the funds. In this context the suggestion could be to inspire the process by Poland, where in 2018 the participatory budget was enshrined in legislation. Based on the analysis of the civic association VIA IURIS (Hrabinová et al., 2020), 3 possible variants of solving the current situation are suggested here:

- To define the participatory budget in Act no. 583/2004 Coll. on budgetary rules of territorial self-government in terms of official expenditures of the municipality. The law would thus contain a 
definition of a participatory budget, while municipalities would have the power to specify its conditions and settings.

- To define the participatory budget in Act no. 583/2004 Coll. on budgetary rules of territorial self-government in terms of establishing the principles of participatory budgeting. However, the actual application of this tool would already be on a voluntary basis. Putting the participatory budget into practice would thus not be an obligation but would be fully subject to the will of the local authorities

- To define the participatory budget in Act no. 583/2004 Coll. on budgetary rules of territorial self-government in terms of the obligation of the instrument for municipalities in the specific minimum amount of implementation of the participatory budget.

\section{CONCLUSION}

The participatory budget is a relatively widespread tool, especially in Poland, the Czech Republic and Poland within the Visegrad Group countries. It is an instrument of civic participation, which has become a relatively important element in the implementation of municipal policy, especially in Poland, apart from Hungary, where its successful application is still at the beginning. The functioning of the participatory budget in the countries takes place through long-term cooperation between the local government and the non-profit sector. The civic sector has become a decisive factor and an initiator based on examples from abroad. The paper analysed the pilot projects introduced in 2011 in Poland and Slovakia, in 2014 in the Czech Republic, and in 2016 in Hungary. In the case of Poland, this was not a brandnew element of the form of local policy implementation, as a similar attempt by public-private partnerships was identified in 2003-2005. This experiment took place in Plock, but in retrospect it cannot be considered a participatory budget as it did not fulfil the recognised criteria. In the paper, the authors pointed out the shortcomings in the form of low citizen participation in the proposal phase and in the voting process. The paper also identified the same bottom-up implementation process in all V4 member countries. As for voting, just an example of the Polish city of Sopot was conducted to vote that combined "physical" voting and online voting. Gradually, with the expansion of the participatory budget, a combination of different kinds of voting was supposed to achieve the broadest possible citizen participation. A research question on legislative settings has shown that only Poland has enshrined primary legislation on participatory budgets in its legal system. Except 
for Portugal, Italy and Spain, this is the only country with such a strictly regulated participatory budget legislation. Since 2018, it is even the duty of cities with powiat status to implement participatory budget projects, which can be assessed as a problematic solution, especially regarding the Covid-19 crisis. This provision has resulted in several municipalities requiring some change. These municipalities argued that in the crisis - time there was a shortfall in tax revenues and thus they face more difficult conditions in matters of the participatory budget implementation. The participatory budgets of Slovakia, the Czech Republic, and Hungary are based on by-laws. The third research question on the expansion of participatory budgets led to a finding, which shows a continuous increase in the number participatory budget projects. However, a major turning point is associated with the coronavirus pandemic of 2020, when many participatory budgets were cancelled or switched to a two-year cycle.

\section{Acknowledgement:}

This paper was prepared within the project: KEGA 001UCM-4/2019 Dynamika premien verejnej správy SR.

\section{REFERENCES}

ALLEGRETTI, G. and COPELLO, K. (2018), Winding around money issues. What's new in $\mathrm{PB}$ and which windows of opportunity are being opened? In: Dias, N. ed. Hope for democracy: 30 years of participatory budgeting worldwide. Faro: Epopeia Records. pp. 34-53.

BAIOCCHI, G. and GANUZA, E. (2015) Becoming a Best Practice: Neoliberalism and the Curious Case of Participatory Budgeting. In: Lee, C. W., Mcquarrie, M. and Walker, E. T. eds. Democratizing Inequalities: Dilemmas of the New Public Participation. [online]. NYU Press. pp. 187-203. DOI: http://www. jstor.org/stable/j.ctt1287js3.14. [Accessed December 9, 2021].

BARANOWSKI, J. (2020). Participatory Budget and the SARS-COV-2 Pandemic in Poland. In: Transylvanian Review of Administrative Sciences. Special Issue 2020, [online] pp. 24-37. DOI: http://dx.doi.org/10.24193/ tras.SI2020.2. [Accessed December 9, 2021]

BARDOVIČ, J. and GAŠPARÍK, J. (2021). Enablers of Participatory Budgeting in Slovakia during the COVID-19 Pandemic. In: Scientific Papers of the University of Pardubice, Series D, Faculty of Economics and Administration. [online]. Vol. 29, No. 1, Article no. 1248. DOI: https://doi.org/10.46585/ sp29011248 [Accessed November 8, 2021]. 
BEDNARSKA-OLEJNICZAK, D. and OLEJNICZAK, J. (2021). Participatory Budgeting World Atlas. [online]. Available at: https://www.pbatlas.net/ poland.html [Accessed August 23, 2021].

BEZROBOCIE REJESTROWANE. 2011. (2011). [online]. Available at: https://stat.gov.pl/obszary-tematyczne/rynek-pracy/bezrobocierejestrowane/. [Accessed November 11, 2021].

BRABEC, D. (2019). Participatory Budgeting in the Czech Republic between 2014 and 2018. In: Annales Universitatis Mariae Curie-Skłodowska, sectio $K$ - Politologia. [online]. Vol. 26, No. 2. pp. 91-101. DOI: http://dx.doi. org/10.17951/k.2019.26.2.91-101. [Accessed November 9, 2021].

BRIX, R. (2020). Participatívny rozpočet v podmienkach SR. In: Palúš, I., Mital', O. and Žofčinová, V. eds. Verejná správa v súčasnom demokratickom a právnom štáte. Čast'. 2. Košice: Univerzita Pavla Jozefa Šafárika v Košiciach, pp. 278-286.

BRUTOVSKÁ, G. and HREHOVÁ, D. (2019). Participatívne rozpočtovanie na lokálnej úrovni. In: Rovenská, D. and Župová, E. eds. Byrokracia verzus vedomostná organizácia v prostredí verejnej správy. Košice: FVS UPJŠ. pp. 29-49. DOI: https://doi.org/10.33542/BVV2019-822-4.

BRUTOVSKÁ, G. and MAROŠIOVÁ, L. (2019). Inšpiratívne riešenia zapájania obyvatelov do rozhodovacích procesov. Prípadové štúdie zo siedmych samospráv na Slovensku. Wellgiving, 79 pp.

Budapest's Participatory Budget Greenlights 15 Projects Worth HUF 1 Billion. (2021). [online]. Available at: https://www.themayor.eu/en/a/view/ budapest-s-participatory-budget-greenlights-15-projects-worth-huf-1billion-8735 [Accessed August 24, 2021].

BUELE, I. et al. (2020). The Participatory Budgeting and Its contribution to Local Management and Governance: Review of Experience of Rural Communities from the Ecuadorian Amazon Rainforest. In: Sustainability. [online]. Vol. 12, No. 11, pp. 1-18. DOI: https://doi.org/10.3390/ su12114659. [Accessed December 27, 2021].

CABANNES, Y. (2015). The impact of participatory budgeting on basic services: municipal practices and evidence from the field. In: Enviroment and Urbanization. Vol. 27, No, 13, pp. 257-284. DOI: https://doi. org/10.1177/0956247815572297.

ČERNÝ, V. (2016). Metodika tvorby participativního rozpočtu pro města $v$ ČR. Praha: Agora CE, 46 pp. [online]. Available at: https://www.participativnirozpocet.cz/wp-content/uploads/2017 /05/Metodika_Participativni_ rozpocet_AGORA_CE.pdf [Accessed December 8, 2021]. 
CEVÁROVÁ, D. (2020). Občianska participáciav samosprávach - participatívny rozpočet. In: Reflexie praxe na otázky verejnej politiky, ekonómie, práva a verejnej správy Slovenska III. Vysoká škola Danubius. pp. 34-42.

ČUNDERLÍK, L. (2015). Participatívne financovanie na úrovni územnej samosprávy. Participatívna demokracia v 21. storočí. In: Čičkánová, D., Hapčová, I. and Mičátek, V. eds. Bratislavské právnické fórum. Bratislava: Bratislava: PrF UK. pp. 1029-1036.

DE VRIES, M., NEMEC, J. and ŠPAČEK, D. (2021). International Trends in Participatory Budgeting : Between Trivial Pursuits and Best Practices. Cham/Switzerland: Springer Nature Switzerland AG, 2021. 317 pp. DOI: https://doi.org/10.1007/978-3-030-79930-4.

DEMNET. (2021). [online]. Participatory Budgeting - Budapest Residents to Decide about 1 Billion Forints. Available at: https://demnet.hu/en/ reszveteli-koltsegvetes-budapest-2021/ [Accessed August 13, 2021].

DIAS, N. (2018). Hope for democracy: 30 Years of Participatory Budgeting Worldwide. Faro: Epopeia Records, 2018. 638 pp.

DŽINIĆ, J., MURRAY SVIDROŇOVÁ, M. and MARKOWSKA-BZDUCHA, E. (2016). Participatory Budgeting: A Comparative Study of Croatia, Poland, and Slovakia. In: NISPAcee Journal of Public Administration and Policy. Vol 9, No, 1. pp. 31-56. DOI: https://doi.org/10.1515/nispa-2016-0002 [Accessed November 23, 2021].

FEDOZZI, L. (2007). Observando o Orçamento participativo de Porto Alegre. Porto Alegre. Milano: Tomo, 2007. 124 pp.

FRIANT, M. C. (2017). Sustainability from Below: Participatory Budgeting in Porto Alegre. [online]. Available at: https://www.academia. edu/17982375/Sustainability_From_Below_ Participatory_Budgeting [Accessed August 12, 2021].

GANUZA, E. and BAIOCCHI, G. (2012). The Power of ambiguity: How Participatory Budgeting Travels the Globe. In: Journal of Public Deliberation. Vol 8, No. 2, Article No. 8. [online]. DOI: https://doi. org/10.16997/jdd.142. [Accessed August 13, 2021].

GARAJ, M. and BARDOVIČ, J. (2020). Participatory budgeting- the Case of Slovak Republic. In: Annales Universitatis Mariae Curie-Skłodowska, sectio $K$ - Politologia. [online]. Vol. 27, No. 2, pp. 59-73. DOI: http://dx.doi. org/10.17951/k.2020.27.2.59-73. [Accessed November 9, 2021].

GERWIN, M. and GRABKOWSKA, M. (2012). Budżet obywatelski. In: Przewodnik Krytyki Politycznej. Warszaw: Wydawnictwo Krytyki Politycznej. pp. 100-111. 
GOLDFRANK, B. (2006). Lessons from Latin American experience in participatory budgeting. In: Participatory budgeting. [online]. Vol 14, No 4, 2007. pp. 91-126. Available at: https://pdfs.semanticscholar. org/27b5/f3406e7aeaa48974007489253bb4525b6df2.pdf [Accessed August 13, 2013].

HRABINOVÁ, A. et al. (2020). X+1 otázok a odpovedí o participatívnom rozpočte. Bratislava: MV SR. 127 pp.

KEBLOWSKI, W. and VAN CRIEKINGENB, M. (2014). Participatory Budgeting Polish-Style. What Kind of Policy Practice Has Travelled to Sopot, Poland? In: Dias, N. ed. Hope for Democracy - 25 years of participatory budgeting worldwide. Sao Bras de Alportel: In Loco Association. pp. 369-377.

KLIMOVSKÝ, D. and GAŠPARÍK, J. (2020). Základný rámec participatívnej tvorby verejných politík a súvisiace pojmy. In: Klimovský, D. ed. Participatívne procesy $v$ praxi čítanka participatívnej tvorby verejných politík. Bratislava: MV SR/ÚSR ROS. pp. 12-26.

KRENJOVA, J. and RAUDLA, R. (2013). Participatory Budgeting at the Local Level: Challenges and Opportunities for New Democracies. In: Halduskultuur - Administrative Culture. Vol. 14, No 1. pp 18-46.

MADEJ, M. (2019). Participatory Budgeting in the Major Polish Cities- Case Study of 2018. In: Politics in Central Europe. Vol 15, No 2. pp. 257-277. DOI: https://doi.org/10.2478/pce-2019-0017.

MARCZEWSKA-RYTKO, M. and MAJ, D. (2021). Civic/Participatory Budget in the Visegrad Group Countries in the Context of Good Practices. Lublin: Maria Curie- Sklodowska University Press, 243 pp.

MARCZEWSKA-RYTKO, M. et al. (2018). Civic participation in the Visegrad Group countries after 1989. Lublin: Marie Curie Sklodowska University Press. 226 pp.

MARKOWSKI, K. (2019). Participatory Budgeting in Poland AD 2019: Expectations, Changes and Reality. In: Polish Political Science Yearbook. Vol 48, No. 4. pp. 642-652. DOI: https://doi.org/10.15804/ppsy2019409. MIKUŠ, D. and NOVÁK, M. (2020). Participatory budget as a tool of modern management methods in local government. In: Politics and Knowledge: New Trends in Social Research. Bologna: Filodiritto Publisher. pp. 292301.

MIMOVLÁDNÍ ORGANIZACE AGORA CE (2021). [online]. Available at: http://agorace.cz/o-nas/ [Accessed August 23, 2021].

MIMOVLÁDNÍ ORGANIZACE ALTERNATIVA ZDOLA. (2021). [online]. Available at: http://alternativazdola.cz/o-nasi-organizaci [Accessed August 23, 2021]. 
MINÁRIK, P. (2020). Participatory Budgeting and Traditional Participation in Czech Municipalities. In: Slovak Journal of Political Sciences. Vol 20, No 1. pp. 29-48. DOI: https://doi.org/10.34135/sjps.200102.

MURRAY SVIDROŇOVÁ, M. and GONDÁŠOVÁ, L. (2016). Participatory budgeting as an innovation in local public services delivery: the Slovak case. In: Current trends in public sector research: Proceedings of the $20^{\text {th }}$ international scientific conference. Brno: Masarykova univerzita. pp. 248-256.

NEUBAUEROVÁ, E. and ZUBAL'OVÁ, A. (2012). Nové trendy vo fiškálnej politike - rodovo citlivé rozpočtovanie. In: Ekonomické rozhl'ady - vedecký časopis Ekonomickej univerzity v Bratislave. Vol. 41, No. 1. pp. 7-18.

NORRIS, P. (2002). Democratic Phoenix. Reinventing Political Activism. New York: Cambridge University Press. 290 pp. DOI: https://doi.org/10.1017/ CB09780511610073.

OROSS, D. and KISS, G. (2021). More than just an experiment? Politicians arguments behind introducing participatory budgeting in Budapest. In: Acta Politica. [online]. DOI: https://doi.org/10.1057/s41269-02100223-6.

PARTICIPATIVNÍ ROZPOČET. (2020). Města využívají participativní rozpočtování stále častěji. [online]. Available at: https://www. participativni-rozpocet.cz/blog/2021/02/09/participativni-hlasovaniv-roce-2020 [Accessed August 24, 2021].

PARTICIPATIVNÍ ROZPOČTYVČESKÉ REPUBLICE. (2019). [online]. Available at: https://www.participativni-rozpocet.cz/blog/2020/02/07/ participativni-rozpocty-v-ceske-republice-v-roce-2019/ [Accessed August 24, 2021].

POMARANSKI, M. (2016). Impediments to public consultations in the Polish local self-government. In: Bratislava Law Review. Vol. 3, No. 1. pp. 70-80. DOI: https://doi.org/10.46282/blr.2019.3.1.134.

SINTOMER, Y., RÖCKE, A. and HERZBEREG, C. (2016). Participatorybudgeting in Europe, Democracy and public governance. Amsterdam: ROUTLEDGE. 251 pp. DOI: https://doi.org/10.4324/9781315599472.

SINTOMER, Y., HERZBERG, C. and RÖCKE, A. (2008). Participatory Budgeting in Europe: Potentials and Limitations of Participatory Budgeting. In: International Journal of Urban and Regional Research. Vol. 32, No. 1, pp. 164-178. DOI: https://doi.org/10.1111/j.1468-2427.2008.00777.x. SIPOS, M. and RESZKETŐ, P. E. (2019). Budapest participatory budget case study report. [online]. Available at: https://www.participativnirozpocet.cz/wp-content/uploads/2019/03/REPORT_BUDAPEST-PB.pdf [Accessed August 25, 2021]. 
SZÉKELY. G. (2020). Participatory Budgeting in Slovakia: possibilities, limits and experience in practice. In: Polityčni partiji i vybory: ukrajinski ta svitovi praktyky. L'vov: L'vivskyj nacional'nyj universytet imeni Ivana Franka, pp.181-208.

VRÁBLÍKOVÁ, K. (2009). Politická participace a její determinanty v postkomunistických zemích. In: Sociologický časopis / Czech Sociological Review. Vol. 45, No. 5. pp. 867-897. D0I: https://doi.org/10.13060/0038 0288.2009.45.5.01.

VÝSLEDKY PARTICIPATÍVNEHO ROZPOČTU 2014. (2014). [online]. Available at: https://pr.banm.sk/liferay/pr2014 [Accessed August 24, 2014].

WAMPLER, B. (2012). Participatory Budgeting: Core Principles and Key Impacts. In: Journal of Public Deliberation. Vol. 8, No. 2. Article no. 12. DOI: https://doi.org/10.16997/jdd.138. 